\title{
Influence of Nanoclay Content on Cement Matrix for Oil Wells Subjected to Cyclic Steam Injection
}

\author{
Ahmed Abdulhamid Mahmoud $₫$, Salaheldin Elkatatny *®o, Abdulmalek Ahmed \\ and Rahul Gajbhiye \\ College of Petroleum Engineering and Geosciences, King Fahd University of Petroleum \& Minerals, \\ 31261 Dhahran, Saudi Arabia; g201205160@kfupm.edu.sa (A.A.M.); g201080240@kfupm.edu.sa (A.A.); \\ rahulg@kfupm.edu.sa (R.G.) \\ * Correspondence: elkatatny@kfupm.edu.sa; Tel.: +966-594663692
}

Received: 1 April 2019; Accepted: 29 April 2019; Published: 5 May 2019

\begin{abstract}
High-temperature conditions drastically compromise the physical properties of cement, especially, its strengths. In this work, the influence of adding nanoclay (NC) particles to Saudi class $\mathrm{G}$ oil well cement (OWC) strength retrogression resistance under high-temperature condition (300 ${ }^{\circ} \mathrm{C}$ ) is evaluated. Six cement slurries with different concentrations of silica flour (SF) and NC were prepared and tested under conditions of $38^{\circ} \mathrm{C}$ and $300{ }^{\circ} \mathrm{C}$ for different time periods ( 7 and 28 days) of curing. The changes in the cement matrix compressive and tensile strengths, permeability, loss in the absorbed water, and the cement slurry rheology were evaluated as a function of NC content and temperature, the changes in the structure of the cement surfaces were investigated through the optical microscope. The results revealed that the use of NC (up to 3\% by weight of cement (BWOC)) can prevent the OWC deterioration under extremely high-temperature conditions. Incorporating more than $3 \%$ of NC severely damaged the cement matrix microstructure due to the agglomeration of the nanoparticles. Incorporation of NC particles increased all the cement slurry rheological properties.
\end{abstract}

Keywords: cement retrogression resistance; Saudi class G cement; oil well cement; nanoclay particles; cyclic steam injection

\section{Introduction}

The main functions of the primary cementing in oil wells is to provide the desired mechanical stability, prevent any communication between the drilled formations by preventing the cement/formation annulus being present, protect the casing from being contacted by the formation of corrosive fluids so no microcracks should be present in the cement sheath, and prevent the fluids from flowing up toward the surface through the cement/formation annulus, microcracks in the cement sheath, and/or casing/cement annulus. In these kinds of operation, the wellbore/casing annular space is filled by one or more cement slurries which must form strong enough and durable cement matrix to meet the needed isolation efficiency throughout the well life without the need for any minimal corrective interventions. To achieve these goals, the cementing project must be well evaluated, discussed, planned and executed [1,2].

One of the most essential parameters to be considered during the design of the cement slurry is the temperature to which the cement sheath will be subjected. The effect of the temperature on both the liquid phase when the slurry is pumped through the casing/wellbore annular space, and on the solid phase (hydrate cement) when the cement matrix is required to meet the physical and chemical properties considered when the cement program is designed, was earlier addressed by different studies [2-7]. 
Alteration of the mechanical properties of hydrated Portland cement is expected at high-temperature conditions, since the elevated temperature adversely effects on the cement hydrated products [6,8-15]. The conditions of elevated temperature are expected in deep wells, geothermal wells, and wells subjected to steam injection for enhanced oil recovery (EOR) applications, since the injected steam is able to decrease the oil viscosity, and hence, increase its mobility and finally enhance the oil production [16]. Currently, thermal oil recovery is a widely used technique around the world to produce heavy oil in many projects, examples are: (a) Kern Field in California, USA; (b) the Athabasca Oil Sands in Alberta, Canada; (c) Mene Grande in Venezuela; (d) Northeast Region in Brazil; and (e) the Surplacul de Barcau Field in Romania, [17-19].

Portland cement experiences major chemical and microstructural transformations under high-temperature conditions (when the temperature exceeds $110^{\circ} \mathrm{C}$ ), such a phenomenon is known as strength retrogression which intensifies as long as the temperature increases beyond $110^{\circ} \mathrm{C}[3,20,21]$. During the strength retrogression transformation, calcium-rich products are formed in the cement matrix, which will result in an increase of the matrix permeability and a deterioration of its mechanical properties.

Several early studies confirmed that when the temperature exceeds $110{ }^{\circ} \mathrm{C}$, and based on the temperature value, the addition of the silica $\left(\mathrm{SiO}_{2}\right)$ particles (usually greater than $30 \%$ by weight of cement (BWOC)) into the cement could considerably enhance the cement resistance to the strength retrogression [7]. Interaction of the reactive $\mathrm{SiO}_{2}$ particles with portlandite phase $\left(\mathrm{Ca}(\mathrm{OH})_{2}\right.$ or $\left.\mathrm{CH}\right)$, which is one of the main products of the cement hydration process, usually lead to formation of another stable phase of calcium silicate hydrated (C-S-H) species like tobermorite, trucostite, and xonotlite which are able to enhance the cement matrix mechanical properties [20-24]. Anti-retrogression agents are materials rich in silica such as silica sand and silica flour, which are mostly added to the oil well cement (OWC).

Table 1 summarizes the reaction velocities of the silicate (pozzolan) cement hydration and the reaction of $\mathrm{CH}$ with the slow pozzolans. This table shows that the reaction of the slow pozzolans such as nanoclay (NC) with $\mathrm{CH}$ is a slow reaction compared to the other reactions happen during the cement hydration process.

Table 1. Cement hydration and slow pozzolans reaction description, modified after Bezerra et al. [25].

\begin{tabular}{cc}
\hline Reaction & Reaction Velocity \\
\hline $2 \mathrm{C}_{3} \mathrm{~S}+6 \mathrm{H} \rightarrow \mathrm{C}-\mathrm{S}-\mathrm{H}(61 \%)+\mathrm{CH}$ & Fast $\rightarrow$ hours and days \\
$2 \mathrm{C}_{2} \mathrm{~S}+4 \mathrm{H} \rightarrow \mathrm{C}-\mathrm{S}-\mathrm{H}(82 \%)+\mathrm{CH}$ & Fast $\rightarrow$ days \\
Slow Pozzolans $+\mathrm{CH}+\mathrm{H} \rightarrow$ C-S-H (pozzolanic reaction) & Slow $\rightarrow$ days to months \\
\hline
\end{tabular}

Costa et al. [6] examined the use of silica particles to enhance the oil wells cement resistance to the high-temperature conditions. As a result, they reported that the optimum concentration of silica particles that could considerably enhance the cement resistance to the high-temperature conditions of $300{ }^{\circ} \mathrm{C}$ is $35 \%$ BWOC.

The NC particles are currently used in the cement industry to enhance the strength of the cement matrix because of their ability to fill the capillary microporous of the matrix due to their considerably small size, the property which will increase the density of the solidified cement. Sanjuán et al. [26] reported that the decrease in the particle size of the pozzolanic materials (such materials like NC and silica fume) considerably improved the cement strength. Wang [7] studied the effect of replacing the ordinary Portland cement (OPC) with 0.1 to $0.5 \%$ of the NC particles on the concrete strength at a variable temperature from 25 to $1000{ }^{\circ} \mathrm{C}$. As a result, Wang [7] reported that the NC particles are able to enhance the concrete compressive strength with the increase of the temperature up to $300^{\circ} \mathrm{C}$; a significant decrease in the concrete compressive strength was noticed when the temperature is between 440 to $580^{\circ} \mathrm{C}$, and the compressive strength of the concrete reduced to about $10 \%$ of the original strength when the temperature reached $1000^{\circ} \mathrm{C}$. 
The NC particles are characterized by their extremely large surface area and very small particle size, such properties accelerate the reactions happen during the cement hydration process, and hence, more secondary C-S-H gel will be produced which will effectively fill the cement matrix capillary pores [27-29], and thus, densifying the microstructure of the matrix.

The aim of this study is to evaluate the applicability of adding different percentages of NC with and without $35 \%$ BWOC of silica flour (SF) particles to Saudi class G oil well cement (OWC) to enhance its compressive strength under high-temperature conditions $\left(300{ }^{\circ} \mathrm{C}\right)$ encountered in geothermal environments and in wells experience cyclic steam injection.

\section{Methodology}

In this study, exposure of the cement samples to high temperature $\left(300{ }^{\circ} \mathrm{C}\right)$ was considered and followed by the analysis of the mechanical behavior of the cement samples.

\subsection{Materials}

The slurries considered in this study were formulated using Saudi class G cement, silica flour, friction reducer additive, different concentrations of the NC particles, and deionized water. The cement slurries compositions are summarized in Table 2.

Table 2. Cement slurries compositions.

\begin{tabular}{|c|c|c|c|c|c|}
\hline Slurries & $\begin{array}{l}\text { Cement } \\
\text { (g) }\end{array}$ & $\begin{array}{l}\text { Silica Flour } \\
\text { (\%BWOC) }\end{array}$ & $\begin{array}{c}\text { Friction Reducer } \\
\text { (\%BWOC) }\end{array}$ & $\begin{array}{c}\text { Water } \\
\text { (\%BWOC) }\end{array}$ & $\begin{array}{c}\text { Nanoclay Particles } \\
\text { (\%BWOC) }\end{array}$ \\
\hline SONC0 & 600 & 0 & 0.8 & 44 & 0 \\
\hline S35NC0 & 600 & 35 & 0.8 & 44 & 0 \\
\hline S35NC1 & 600 & 35 & 0.8 & 44 & 1 \\
\hline S35NC2 & 600 & 35 & 0.8 & 44 & 2 \\
\hline S35NC3 & 600 & 35 & 0.8 & 44 & 3 \\
\hline S35NC4 & 600 & 35 & 0.8 & 44 & 4 \\
\hline
\end{tabular}

Saudi class G cement with the specific gravity (SG) of 3.15 and the chemical composition summarized in Table 3 as characterized by X-ray fluorescence (XRF) technique, and the phases composition summarized in Table 4 was used in this study, the phase composition of Saudi Class G cement summarized in:

Table 4 indicates that this type of cement is a high sulfate resistant.

Table 3. Saudi class G cement elemental composition, by X-ray fluorescence (XRF) analysis.

\begin{tabular}{cc}
\hline Component & Concentration (wt.\%) \\
\hline Silica $\left(\mathrm{SiO}_{2}\right)$ & 21.6 \\
Alumina $\left(\mathrm{Al}_{2} \mathrm{O}_{3}\right)$ & 3.30 \\
Iron Oxide $\left(\mathrm{Fe}_{2} \mathrm{O}_{3}\right)$ & 5.99 \\
Calcium Oxide, $\mathrm{Total}_{(\mathrm{CaO})}$ & 64.2 \\
Magnesium Oxide $(\mathrm{MgO})$ & 1.10 \\
Sulphur Trioxide $\left(\mathrm{SO}_{3}\right)$ & 2.20 \\
Loss on Ignition & 0.90 \\
Insoluble Residue & 0.30 \\
Equivalent Alkali $\left(\mathrm{as} \mathrm{Na}_{2} \mathrm{O}\right)$ & 0.41 \\
\hline
\end{tabular}


Table 4. Saudi class G cement phase composition.

\begin{tabular}{cc}
\hline Component & Concentration (wt.\%) \\
\hline $\mathrm{C}_{3} \mathrm{~A}$ & $<1$ \\
$\mathrm{C}_{3} \mathrm{~S}$ & 62 \\
$\mathrm{C}_{2} \mathrm{~S}$ & 15 \\
$\mathrm{C}_{4} \mathrm{AF}+2 \mathrm{C}_{3} \mathrm{~A}$ & 16 \\
\hline
\end{tabular}

Figure 1 shows the particles size distribution (PSD) for the Saudi Class G cement used in this study. As shown in Figure 1 more than half of the cement particles are less than $21.27 \mu \mathrm{m}$, and about $90 \%$ of the cement particles are less than $47.18 \mu \mathrm{m}$.

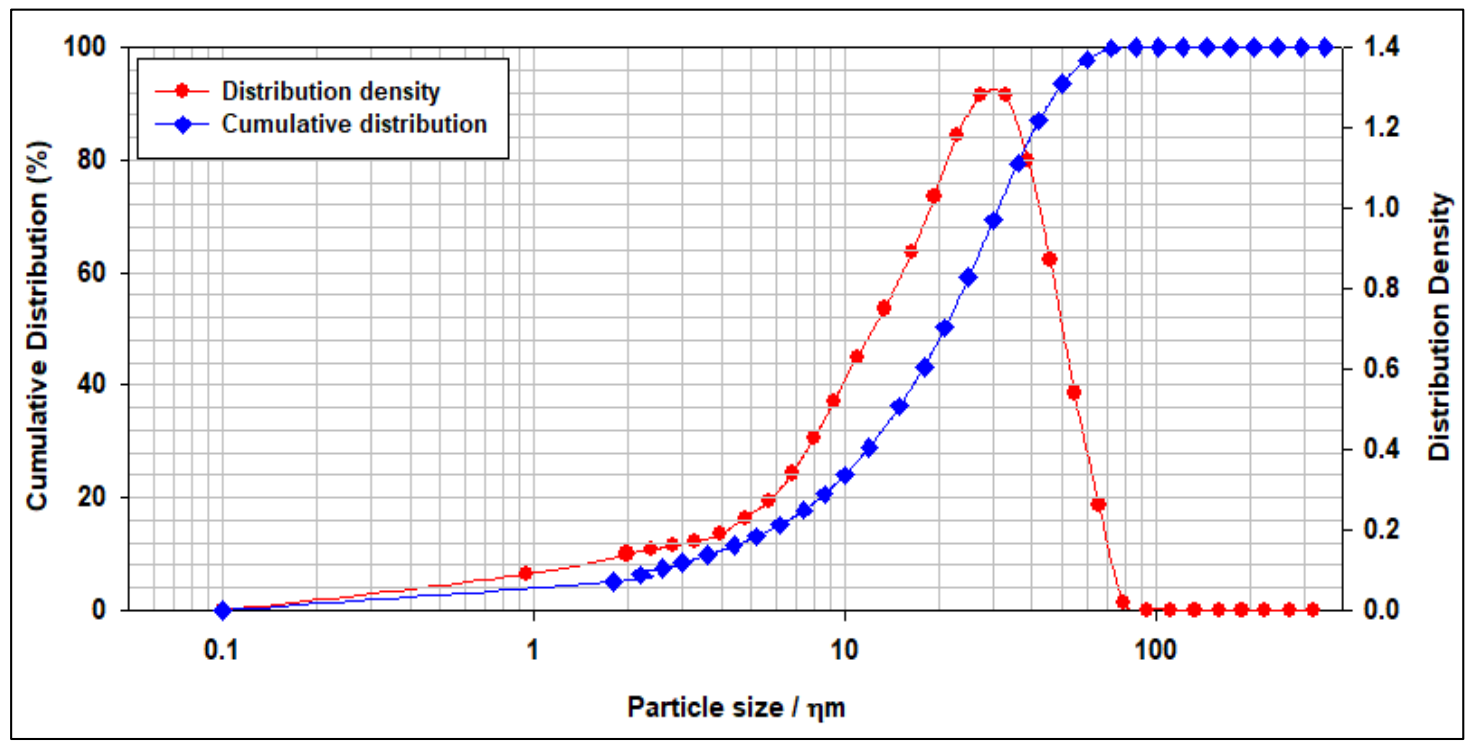

Figure 1. The particles size distribution of Saudi Class G cement.

The silica flour is a material which is composed of more than $99 \% \mathrm{SiO}_{2}[5,30]$ and has an SG of $2.64 \mathrm{~g} / \mathrm{cm}^{3}$, the friction reducer (CFR-3) is a special friction reducer provided by a service company. The deionized water has an SG of 1.0. The NC particles used in this study are modified montmorillonite nanoclays which is organically modified by cation exchange reaction to transform it to more hydrophobic state according to the procedures explained by Rahman et al. [31], the NC particles SG is 1.98 .

Figure 2 shows the PSD for the modified montmorillonite NC particles used in this study. As indicated in Figure 2 more than half of the cement particles are less than $9.69 \mu \mathrm{m}$, and about $90 \%$ of the cement particles are less than $21.46 \mu \mathrm{m}$.

\subsection{Samples Preparation and Curing}

Cement slurries with a density of around $1.97 \mathrm{~g} / \mathrm{cm}^{3}(16.44 \mathrm{ppg})$ were prepared and tested following the American Petroleum Institute procedure [32]. Six slurries with the composition in Table 2 were prepared. The first slurry (SONC0) was prepared without adding SF or NC particles to be considered as the base case. In the second formulation (S35NC0), 35\% BWOC of SF was added, since the $35 \%$ is considered as the optimum silica content for applications of $300{ }^{\circ} \mathrm{C}$ temperature [6], so this formulation ( $\mathrm{S} 35 \mathrm{NC} 0$ ) will be compared with the next formulations which contain the same silica content (i.e., 35\%BWOC) and different concentrations of NC particles. S35NC1, S35NC2, S35NC3 and S35NC4 samples in Table 2 denote the cement slurries incorporating 1, 2, 3, and 4\% BWOC of the NC, respectively. 


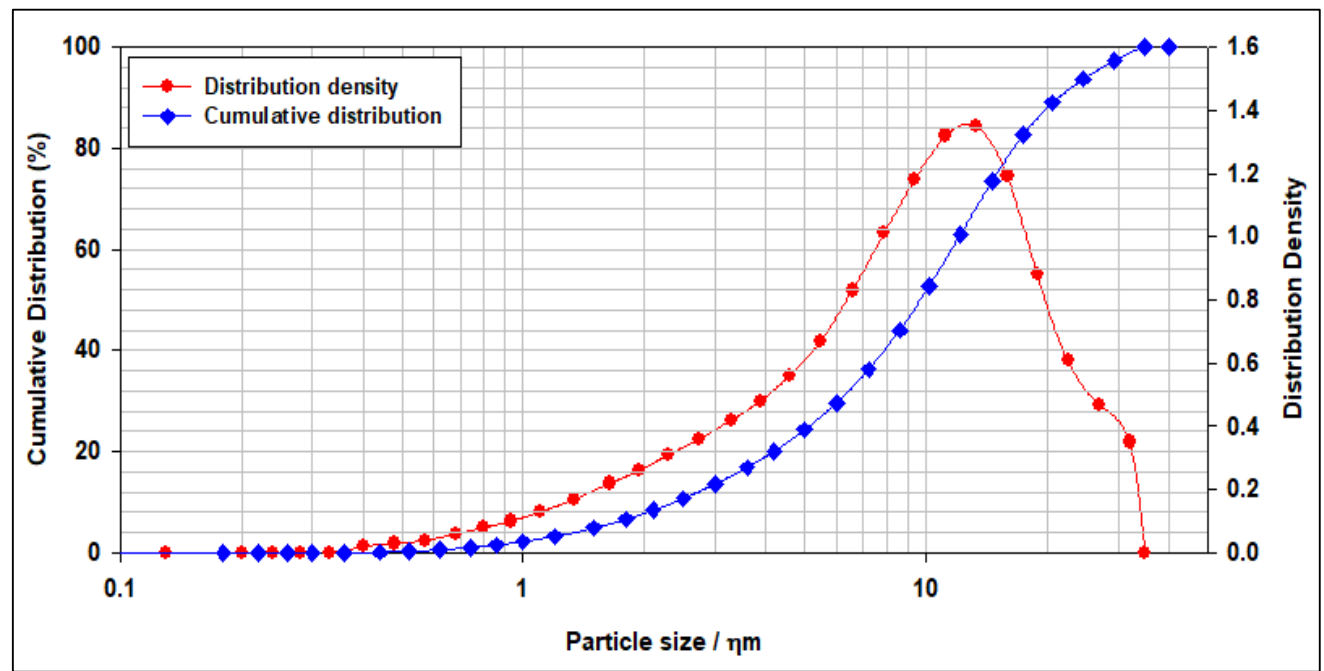

Figure 2. The particles size distribution of the nanoclay (NC) particles.

After preparation, some of the slurries were poured into $50.8 \mathrm{~mm}$ edge metallic cubical molds for compressive strength testing and the remaining poured into cylindrical molds of $38.1 \mathrm{~mm}$ in diameter and $22.9 \mathrm{~mm}$ in length for tensile strength testing, permeability measurements, and water loss testing. The molds were then submerged in a water bath at $38^{\circ} \mathrm{C}$ for a specific time. All the formulations in Table 2 were evaluated in two different scenarios. The low temperature of which $\left(38^{\circ} \mathrm{C}\right)$ was used as a reference, and the high temperature of $300^{\circ} \mathrm{C}$ which was used to represent the average temperature for wells to undergo cyclic steam injection for EOR. In the case of the low temperature, the samples were submerged into the water bath for 7 and 28 days before testing for the compressive and tensile strengths, and permeability. On the other hand, other samples were kept into the water bath at the low temperature of $38^{\circ} \mathrm{C}$ for 4 and 25 days and then subjected to the high temperature of $300{ }^{\circ} \mathrm{C}$ and $20.68 \mathrm{MPa}$ for more three days to represent one cycle of steam injection condition, after that these samples were tested for the same properties evaluated in the case of the low-temperature scenario. Table 5 summarizes the curing conditions for the different scenarios considered in this study.

Table 5. Curing time procedure.

\begin{tabular}{c} 
Curing Time \\
\hline $38{ }^{\circ} \mathrm{C}$ \\
$300{ }^{\circ} \mathrm{C} \quad \begin{array}{c}7 \text { days in the water bath } \\
28 \text { days in the water bath }\end{array}$ \\
$\begin{array}{r}7 \text { days, the first } 4 \text { days in the water bath and } \\
\text { the last } 3 \text { days in the curing chamber at } 300{ }^{\circ} \mathrm{C} \text { (one thermal cycle) } \\
28 \text { days, the first } 25 \text { days in the water bath and }\end{array}$ \\
the last 3 days in the curing chamber at $300{ }^{\circ} \mathrm{C}$ (one thermal cycle)
\end{tabular}

\subsection{Compressive Strength Measurement}

Compressive strength of the samples was evaluated based on the API procedure [32]. For each temperature condition (scenarios in Table 5), and for all compositions under study (Table 2) after 7 and 28 days, three cubical samples with $50.8 \mathrm{~mm}$ edge were used to evaluate the cement matrix compressive strength. The compressive strength of every specific composition at a specific temperature condition was calculated based on the average strength of the three tested samples.

\subsection{Permeability Measurement}

Gas permeability of the different cement matrix compositions considered in this study was measured on cylindrical samples of $38.1 \mathrm{~mm}$ in diameter and $22.9 \mathrm{~mm}$ in length, the samples 
permeability was calculated using Hagen-Poiseuille law which is a commonly used law to calculate the permeability for a laminar flow under steady-state conditions of a compressible fluid through a porous material composed of a network of small capillary pores, the permeability was measured according the procedures explained earlier by Sanjuán and Muñoz-Martialay [33].

\subsection{Tensile Strength Measurement}

Cylindrical samples of $38.1 \mathrm{~mm}$ in diameter and $22.9 \mathrm{~mm}$ in length were prepared for the purpose of tensile strength testing. The indirect tensile strength testing method (Brazilian test) was used to measure the maximum load that the sample could resist before falling under tension. Then Equation (1) was used to calculate the tensile strength of the sample.

$$
\sigma_{t}=\frac{2 P}{\pi d l}
$$

where $\sigma_{t}$ denotes the Brazilian tensile strength in (MPa), $P$ is the failure load in $(\mathrm{N}), d$ and $l$ are the cement sample diameter and length, respectively, both are in $(\mathrm{mm})$.

Three cylindrical samples were used to evaluate the cement matrix tensile strength for every specific composition at a specific temperature condition. The tensile strength was then calculated based on the average tensile strength of the three tested samples.

\subsection{Non-Evaporable Water Content}

The samples mass loss due to exposure to a high temperature was investigated, cylindrical samples of $38.1 \mathrm{~mm}$ in diameter and $22.9 \mathrm{~mm}$ in length were aged for 4 and 25 days at $38^{\circ} \mathrm{C}$, then they were firstly oven dried at $105^{\circ} \mathrm{C}$ for $2 \mathrm{~h}$, after this time there was no more water evaporation at $105^{\circ} \mathrm{C}$, the samples were then weighted before and after being subjected to the high temperature of $300^{\circ} \mathrm{C}$ for 3 days. The loss in the weight after exposing the samples to $\left(300^{\circ} \mathrm{C}\right)$ is related to the loss in the amount of the water absorbed by NC particles.

\subsection{Optical Microscope Images}

Cubical samples with $50.8 \mathrm{~mm}$ edge were prepared for the purpose of imaging. After samples curing at $38^{\circ} \mathrm{C}$ for 7 days they were cured at $300{ }^{\circ} \mathrm{C}$ for three more days, then a small cubical slice with the dimensions of $5 \times 5 \times 20 \mathrm{~mm}^{3}$ was cut exactly from the center of each cement cube for the purpose of imaging through optical microscope to study the change in the pore structure of the cement matrix as a function of the SF and NC concentrations. The cement slices were polished prior to the microscope imaging.

\subsection{Rheology}

Addition of NC particles is known to considerably alter the cement rheology as reported earlier by many authors $[34,35]$. Alteration of rheological characteristics for all cement slurries considered in this study was evaluated to address the effect of the NC particles on the cement rheology. The 10-s and 10-min gel strengths (GS), yield point (YP), and plastic viscosity (PV) were evaluated for all of the cement slurries under study.

\section{Results and Discussion}

\subsection{Compressive Strength Results}

In this section, the effect of temperature on the strength retrogression for the different slurries under consideration is evaluated; since the cement strength retrogression is expected to occur when the well temperature exceeds $110^{\circ} \mathrm{C}[21,36]$. Figure 3 compares the change in the strength for all the cement formulations with and without subjecting the cement samples to $300{ }^{\circ} \mathrm{C}$. The base sample (SONC0) which has zero SF and NC content lost $81.12 \%$ and $79.46 \%$ of its original strength after 7 and 
28 days of curing, respectively, when exposed to $300{ }^{\circ} \mathrm{C}$ condition. The strength of the sample S0NC0 after 7 days decreased from 44.5 to $8.4 \mathrm{MPa}$ and after 28 days decreased from 48.2 to $9.9 \mathrm{MPa}$ when undergoes a condition similar to one cycle of steam injection.

When $35 \%$ BWOC of the SF only is added to the cement slurry (sample S35NC0), a considerable increase in the cement resistance to the strength retrogression at a temperature of $300{ }^{\circ} \mathrm{C}$ was observed after 7 and 28 days, as shown in Figure 3. The strength of the sample S35NC0 exposed to $300{ }^{\circ} \mathrm{C}$ after 7 days is $41.6 \mathrm{MPa}$ compared to $8.4 \mathrm{Mpa}$ for the base sample (S0NC0), and after 28 days the strength was $43.5 \mathrm{Mpa}$ when the sample subjected to one steam injection cycle condition (Figure 3), which is also very high compared to that of sample S0NC0 (9.9 Mpa), this is attributed to the fact that during the pozzolanic reaction, interaction of $\mathrm{SiO}_{2}$ particles with the $\mathrm{CH}$ leads to the formation of more stable C-S-H products during the hydration process [25].

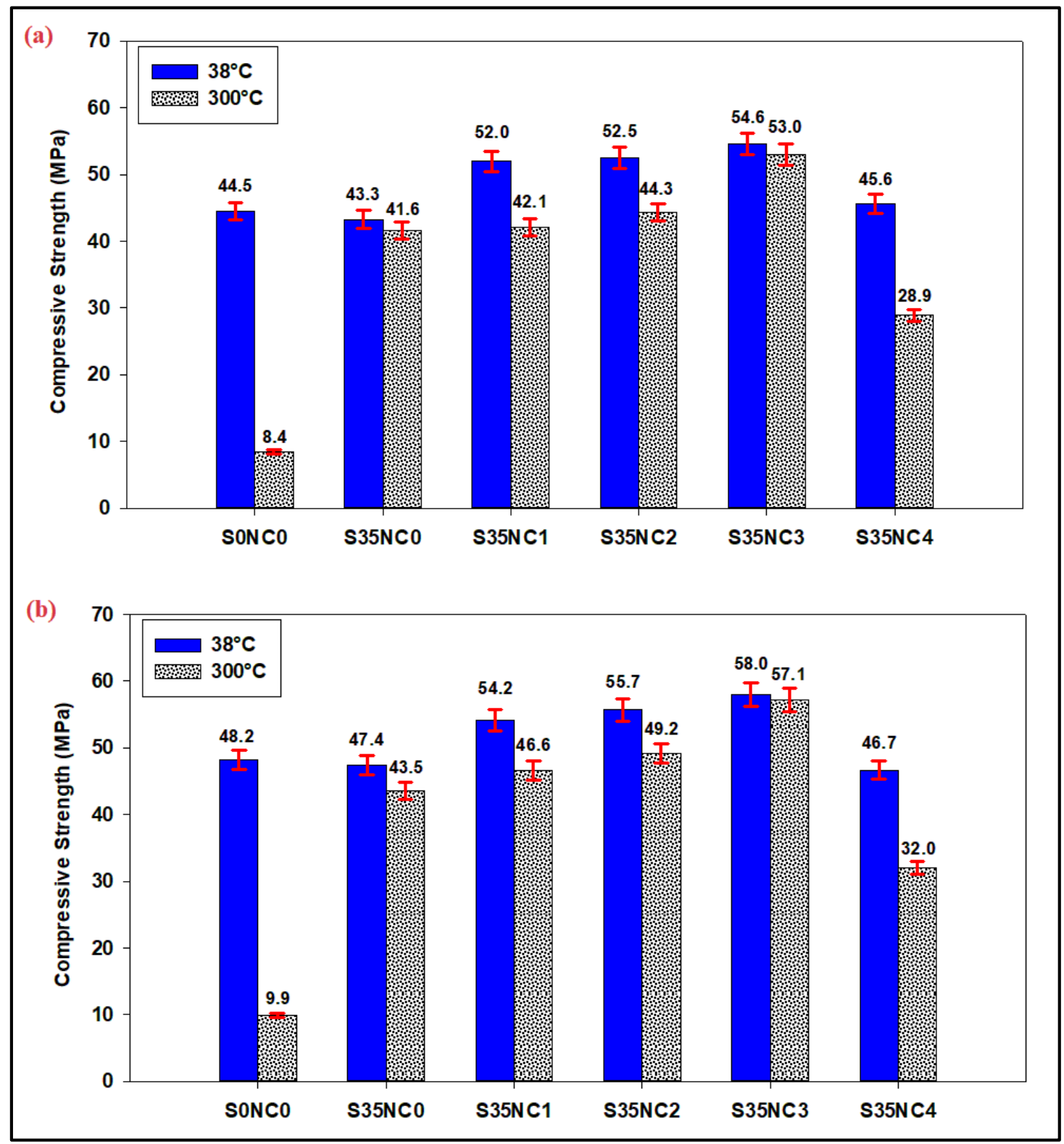

Figure 3. The compressive strength of the samples cured at $38^{\circ} \mathrm{C}$ and $300^{\circ} \mathrm{C}$ after (a) 7 days (b) 28 days.

Addition of NC particles up to 3\% BWOC to the slurry containing 35\% BWOC of SF enhanced the cement strength no matter the temperature used. At low temperature $\left(38^{\circ} \mathrm{C}\right), 3 \%$ of the NC were able to increase the strength of the cement by $26.10 \%$, after 7 days and by $22.36 \%$ after 28 days over 
that obtained by using $35 \%$ of SF only (sample S35NC0), this could be explained as a result of the quick reaction of the NC particles which are characterized by the extremely large surface area and its amorphous state (small particle size) with the free lime during the hydration process, and hence, more secondary C-S-H gel will be produced which will effectively fill the cement matrix capillary pores [27-29], and thus, densify the microstructure of the matrix.

At high temperature $\left(300^{\circ} \mathrm{C}\right)$, adding 1,2 , or $3 \%$ BWOC of the NC particles which are stable at a temperature conditions to the slurry with $35 \% \mathrm{BWOC}$ of SF was able to enhance the strength retrogression resistance compared to the sample S35NC0 which has only SF particles after both 7 and 28 days of curing (Figure 3). The strength increased to $53.0 \mathrm{MPa}$ after 7 days when $3 \%$ NC is added compared to $43.3 \mathrm{MPa}$ for sample S35NC0, and after 28 days the strengths of 57.1 and $43.5 \mathrm{MPa}$ were observed for S35NC3 and S35NC0, respectively.

In both cases of low and high temperatures, addition of $4 \%$ BWOC of NC (sample S35NC4) lead to deterioration of the cement strength. The compressive strength of sample S35NC4 after 7 days in the case of high-temperature scenario becomes $28.9 \mathrm{MPa}$ which is less than that of the sample with zero nanoclay (41.6 MPa), and after 28 days it becomes $32.0 \mathrm{MPa}$, which is again less than that the sample with zero nanoclay $(43.5 \mathrm{MPa})$. This result is attributed to the fact that the use of high concentration of nanoparticles (i.e., more than $3 \%$ ) will lead to nanoparticle agglomeration in the mixes. Formation of weak zones will occur because of these aggregations, which in turn prevents homogenous hydrate formations to form, as a result, the strength of the cement will deteriorate at low-temperature conditions and the strength retrogression resistance will drastically decrease when the cement matrix exposed to high-temperature conditions [37,38].

\subsection{Tensile Strength Results}

The tensile strengths of the cement samples are presented in Figure 4, sample S0NC0 loss $66.30 \%$ and $69.50 \%$ of its tensile strength after 7 (Figure $4 a$ ) and 28 days (Figure $4 \mathrm{~b}$ ), respectively, when subjected to the high-temperature scenario. Including 35\% of SF particles (sample S35NC0) considerably enhanced the cement resistance to failure under tensile force and high-temperature conditions, because of the formation of stable forms of C-S-H during the pozzolanic reaction between the reactive $\mathrm{SiO}_{2}$ and $\mathrm{CH}$ (Table 1) [20]. Incorporating $\mathrm{NC}$ (up to $3 \% \mathrm{BWOC}$ ) into the cement formulation improved its tensile strength linearly under high-temperature conditions, which is a result of the accelerated hydration process.

At high-temperature conditions, sample S35NC3 with 3\% NC and 35\% SF content has tensile strengths of 6.14 (Figure $4 \mathrm{a}$ ) and $6.15 \mathrm{MPa}$ (Figure $4 \mathrm{~b}$ ) after 7 and 28 days, respectively, with an enhancement of $27.39 \%$ and $25.51 \%$ as compared to sample S35NC0 which contains SF only. The cement resistance to tension declined when $4 \%$ of NC is added, since the system overloaded with the nanoparticle, and hence, an irregular microstructure is expected to be developed. Figure 4 shows that sample S35NC4 tensile strengths at low-temperature conditions are 5.56 and $5.80 \mathrm{MPa}$ after 7 and 28 days, respectively, at high-temperature conditions the tensile strengths of sample S35NC4 decreased by $25.10 \%$ and $15.30 \%$ compared to sample S35NC0 after 7 and 28 days respectively.

\subsection{Permeability Measurement Results}

Figure 5 summarizes the permeability measurement results for the cement samples exposed to a condition similar to one cycle of steam injection at $300^{\circ} \mathrm{C}$ for 3 days. These samples firstly cured at $38^{\circ} \mathrm{C}$ using the water bath for 4 days (Figure $5 \mathrm{a}$ ) and 25 days (Figure $5 \mathrm{~b}$ ) then exposed to a high-temperature condition of $300^{\circ} \mathrm{C}$ for three days using a high-pressure and high-temperature (HPHT) curing chamber, the total curing time periods are 7 (Figure 5a) and 28 days (Figure 5b), all cement samples were dried before air permeability measurements as recommended by Sanjuán and Muñoz-Martialay [37]. 


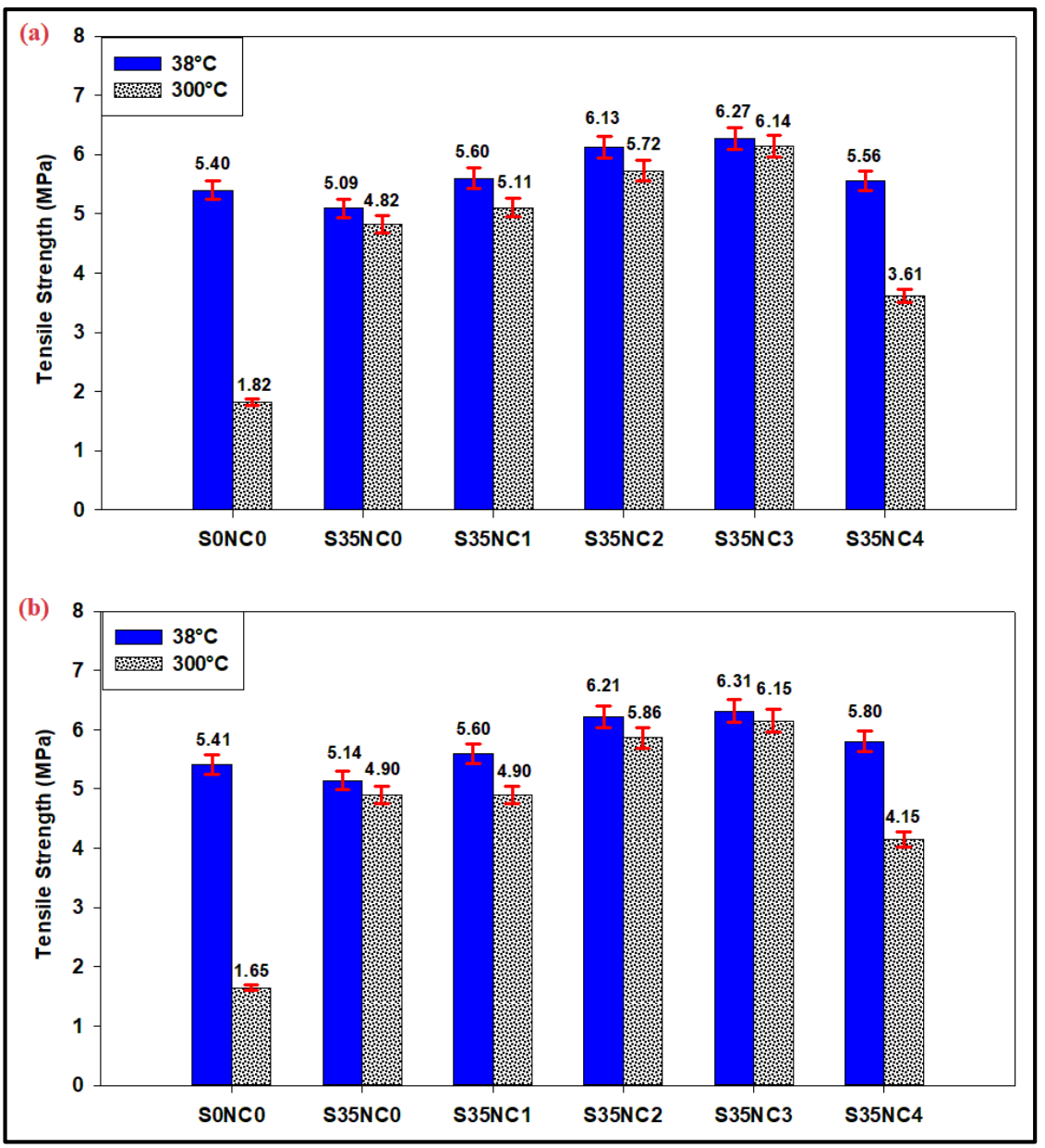

Figure 4. The tensile strength of the samples cured at $38^{\circ} \mathrm{C}$ and $300^{\circ} \mathrm{C}$ after (a) 7 days (b) 28 days.

The base sample (SONC0) has a permeability of 0.0055 and $0.0057 \mathrm{mD}$ after 7 and 28 days, respectively, as shown in Figure 5. This figure also shows that the addition of 35\% SF into the cement formulation (sample S35NC0) was able to decrease the cement permeability by $47.27 \%$ after 7 days (Figure $5 \mathrm{a}$ ) and $54.39 \%$ after 28 days (Figure $5 \mathrm{~b}$ ) compared with sample S0NC0. The cement permeability could be decreased more by incorporating NC particles as indicated in Figure $5 b$, the addition of $2 \%$ NC (sample S35NC2) decreased the cement permeability by $20.69 \%$ and $19.23 \%$ compared to sample S35NC0, which had SF only. When $3 \%$ of NC particles were added, the cement permeability slightly increased (compared to the sample with $2 \% \mathrm{NC}$ ) by 0.0002 (Figure $5 \mathrm{a}$ ) and $0.0003 \mathrm{mD}$ (Figure 5b) after 7 and 28 days, respectively, the reason for this slight increase will be explained in the next section.

Increasing the NC concentration beyond 3\% (i.e., $4 \%$ of nanoclay for sample S35NC4), as in the case of sample S35NC4, lead to a huge increase in the permeability which increased to 0.0052 and $0.0055 \mathrm{mD}$ after 7 and 28 days, respectively, compared with 0.0025 and $0.0024 \mathrm{mD}$ for sample S35NC3. This huge increase in the permeability is caused by the agglomeration of the nanoparticles. The use of a higher concentration of nanoparticles could lead to particles agglomeration as reported earlier by Shebl et al. [38] and Hakamy et al. [39] which results in an irregular microstructure, and hence, high permeability. Then when sample S35NC4 exposed to high-temperature, induced microcracks caused by the irregular microstructure could be easily formed. The evaporated water from the cement matrix and the loss of the water absorbed by nanoclays at high temperature is also responsible about this increase in the permeability as will be explained in the next section.

Table 6 compares between two permeability values for each cement sample at every curing period. For every curing time (i.e., 7 and 28 days) one sample was cured at $38^{\circ} \mathrm{C}$ using the water bath for the whole period while another sample removed and curing at $300^{\circ} \mathrm{C}$ during the last three days of curing 
to represent a condition similar to one cycle of steam injection. Table 6 shows that sample SONC0 which has no SF or NC experienced a considerable increase in its permeability when exposed to $300^{\circ} \mathrm{C}$ during the last three days of curing compared with the same sample cured at low-temperature of $38^{\circ} \mathrm{C}$ for the whole curing period. Sample S0NC0 permeability increased by $71.88 \%$ and $96.55 \%$ after 7 and 28 days, respectively.

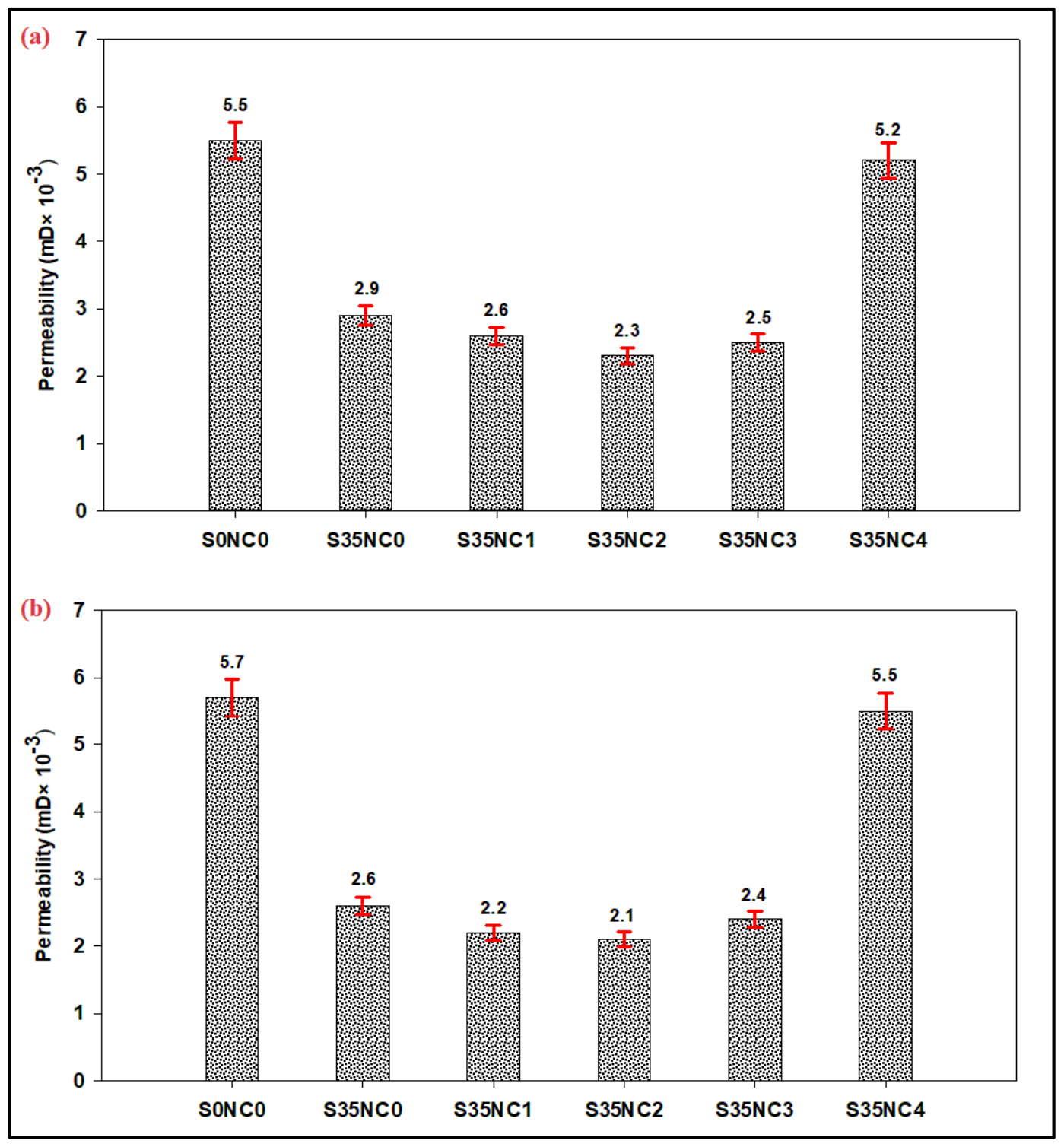

Figure 5. The permeability of the samples after experiencing a condition similar to one cycle of steam injection at $300{ }^{\circ} \mathrm{C}$ for 3 days after being cured at $38^{\circ} \mathrm{C}$ for (a) 4 days (b) 25 days. The total curing times are (a) 7 days and (b) 28 days.

When $35 \%$ BWOC of SF is added (sample S35NC0), the samples permeability at high-temperature condition decreased by $23.68 \%$ and $27.78 \%$ after 7 and 28 days, respectively, compared to the same sample when cured at $38^{\circ} \mathrm{C}$ for the whole curing period (Table 6). This result is attributed to voids filling up due to matrix expansion as the temperature increases as noticed for concrete mortars saturated with silica particles by Farzadnia et al. [40] and because of transformation of the $\mathrm{CH}$ to more stable forms of C-S-H as reported by Heikal et al. [41] and Heikal [42].

It's noticed in Table 6 that the permeability values for all NC based samples increased when exposed to high-temperature conditions compared with the permeability of the same samples when cured at the low-temperature conditions. This increase is very small for the samples with NC of not 
more than 3\%, for example, sample S35NC3 permeability increased by 0.0013 and $0.0014 \mathrm{mD}$ after 7 and 28 days, respectively, after exposure to $300^{\circ} \mathrm{C}$ compared with when sample S35NC3 is cured at low temperature only. Although of this increase all the samples with NC concentrations of not more than 3\% still have permeabilities less than the sample S35NC0 which has no NC particles, as indicated in Figure 5 and Table 6. Sample S35NC4 with 4\% NC experienced a considerable increase in the permeability by $92.56 \%$ and $120 \%$ after 7 and 28 days, respectively, when subjected to $300{ }^{\circ} \mathrm{C}$.

Table 6. The permeability changes in $\left(\mathrm{mD} \times 10^{-3}\right)$ for the cement samples cured for 7 and 28 days. For each case a sample represents every specimen cured at $38^{\circ} \mathrm{C}$ using the water bath for the whole curing time period while another sample removed and cured at $300^{\circ} \mathrm{C}$ during the last 3 days of curing period using the HPHT curing chamber to represent a condition similar to one cycle of steam injection.

\begin{tabular}{ccccc}
\hline \multirow{2}{*}{ Sample } & \multicolumn{2}{c}{$\mathbf{7}$ days } & \multicolumn{2}{c}{$\mathbf{2 8}$ days } \\
\cline { 2 - 5 } & @ $\mathbf{3 8}{ }^{\circ} \mathbf{C}$ & Last $\mathbf{3}$ days $@ \mathbf{3 0 0}{ }^{\circ} \mathbf{C}$ & @ $\mathbf{3 8}{ }^{\circ} \mathbf{C}$ & Last $\mathbf{3}$ days @ $\mathbf{3 0 0}{ }^{\circ} \mathbf{C}$ \\
\hline S0NC0 & 3.2 & 5.5 & 2.9 & 5.7 \\
S35NC0 & 3.8 & 2.9 & 3.6 & 2.6 \\
S35NC1 & 2.1 & 2.6 & 1.9 & 2.2 \\
S35NC2 & 1.7 & 2.3 & 1.6 & 2.1 \\
S35NC3 & 1.2 & 2.5 & 1.0 & 2.4 \\
S35NC4 & 2.7 & 5.2 & 2.5 & 5.5 \\
\hline
\end{tabular}

\subsection{Non-Evaporable Water Content and Optical Microscope Images}

Figure 6 summarizes the mass loss of the samples exposed to $300^{\circ} \mathrm{C}$ for 3 days after being dried for $2 \mathrm{~h}$ at $105^{\circ} \mathrm{C}$. These samples exposed to the high-temperature condition after being aged for 4 and 25 days at low-temperature conditions of $38^{\circ} \mathrm{C}$, so the total aging times are 7 and 28 days (the same second scenario in Table 5). The results in Figure 6 show that the sample with no SF and NC particles lost minor non-evaporable water of $1.21 \%$ and $1.10 \%$ after 7 and 28 days, respectively. This result confirms that the huge increase in the permeabilities of sample SONC0 (Table 6) when exposed to a high-temperature condition is related to the matrix damage and not water evaporation, the optical microscope image in Figure 7 shows that sample S0NC0 has a considerable pore spaces after exposure to $300^{\circ} \mathrm{C}$ which confirm that the increase in the permeability of this sample is related to the increase in the void spaces of the sample.

Incorporating $\mathrm{NC}$ into the cement matrix increased the concentration of the non-evaporable water remains after the samples were dried at $105^{\circ} \mathrm{C}$, which confirms that the increase in the samples S35NC1, S35NC2, and S35NC3 permeabilities after heating the samples at $300{ }^{\circ} \mathrm{C}$ compared to the samples cured at $38^{\circ} \mathrm{C}$ (Table 6) is related mainly to the evaporation of the water absorbed by the NC particles, Figure 7 shows that these samples have fewer void spaces compared with the samples with no NC, which confirm that the increase in the permeability of these samples is not due to cement matrix damage.

Although sample S35NC4 non-evaporable water content is the highest $(6.10 \%$ and $6.23 \%$ after 7 and 28 days, respectively), this does not confirm that the enhancement in the permeability of this sample when subjected to $300^{\circ} \mathrm{C}$ compared with when treated at $38^{\circ} \mathrm{C}$ as shown in Table 6 is mainly related to the non-evaporable water when compared with the non-evaporable water content and permeability increase for sample S35NC3, since both samples have high non-evaporable water concentration but the permeability enhancement for the sample S35NC4 is very high compared to sample S35NC3 Table 6. Figure 7 confirms that sample S35NC4 is dominated by microporous which is a result of a non-uniform microstructure of this sample caused by the agglomeration of the NC particles. 


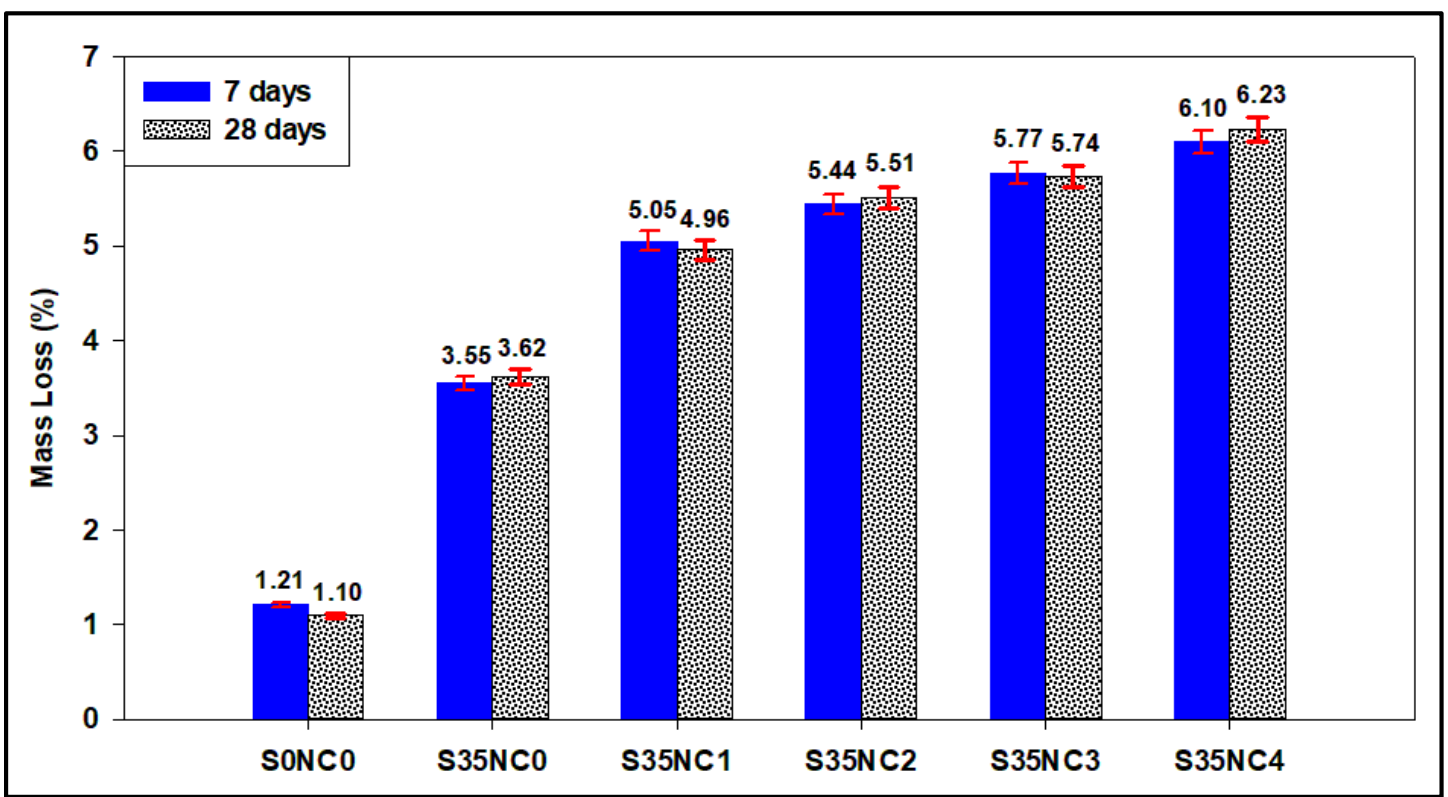

Figure 6. The mass loss after exposing the dried samples to $300{ }^{\circ} \mathrm{C}$ for 3 days.

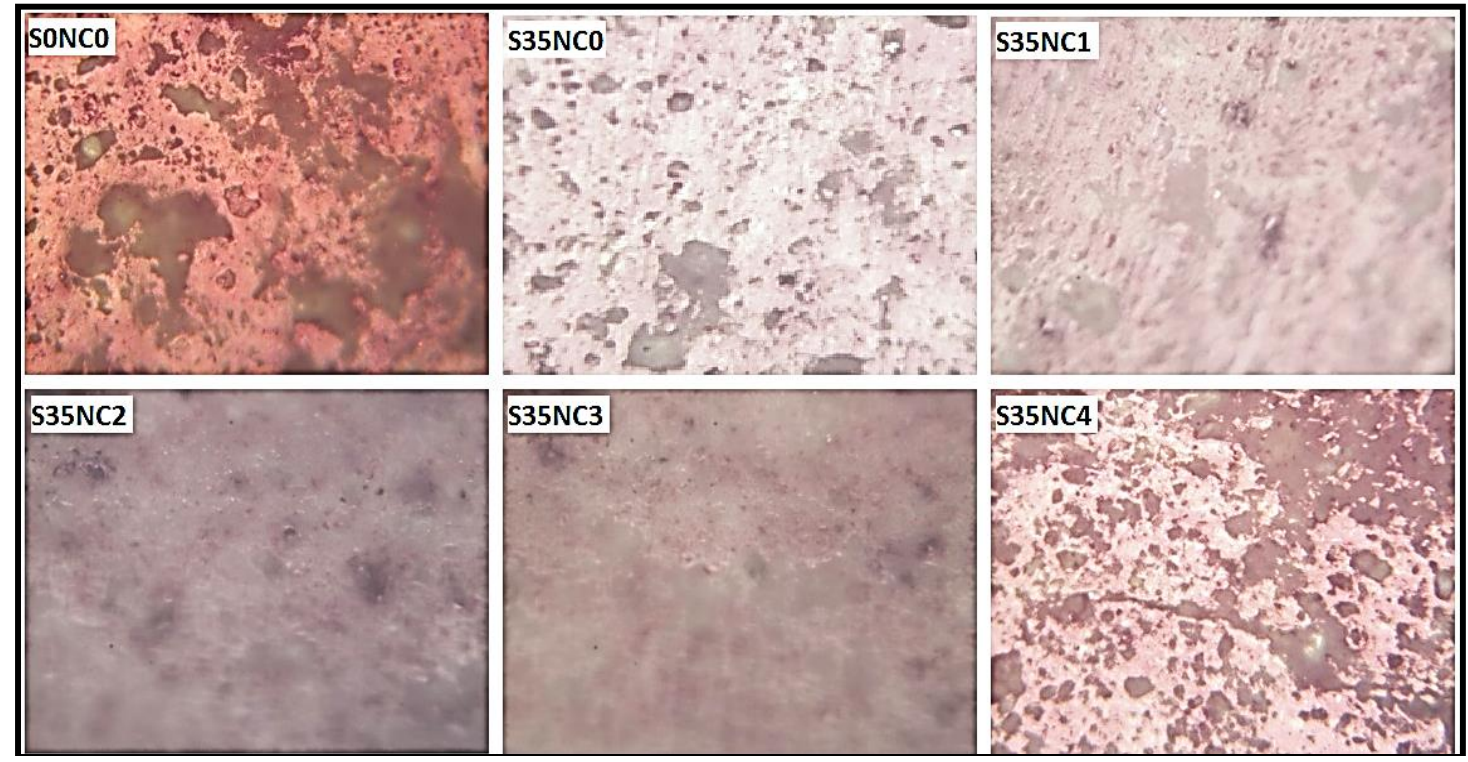

Figure 7. The optical microscopy images of the cement specimens exposed to $300^{\circ} \mathrm{C}$.

\subsection{Effect on Rheological Parameters}

The effect of the NC particles on the rheological characteristics of cement slurry was evaluated. As shown in Figure 8, sample S35NC0 which contain 35\% of the SF and no NC particles had PV and YP of $281 \mathrm{cP}$ and $44.6 \mathrm{lb}_{\mathrm{f}} / 100 \mathrm{ft}^{2}$, respectively. Incorporating NC into the cement slurries increased both the PV and YP of the slurry. Addition of 1\% BWOC of NC to the cement slurry (sample S35NC1) increased the PV and YP of the cement by $7.5 \%$ and $3.6 \%$, respectively, compared to sample S35NC0. Both PV and YP of the cement slurries increased with the increase in the NC concentration to reach $416 \mathrm{cP}$ and $60.9 \mathrm{lb}_{\mathrm{f}} / 100 \mathrm{ft}^{2}$, respectively, for sample S35NC4 containing $4 \%$ BWOC of NC. It is very important to address the change in the PV and YP of the cement slurry; since PV is the main factor controlling the pumpability of the cement slurry from the surface down into the wellbore through the tubing and then up through the annulus between the well casing and the drilled formations, while the increase in the YP of the slurry is required to improve the carrying capacity of the cement slurry. Compared with the base cement slurry, the cement slurries containing NC required high energy to be 
pumped into the well as indicated by the increase in the PV for the samples containing NC. Addition of the NC particles into the cement slurry also increased its YP, which means prevention of solids segregation and settlement of fine particles while cement is injected to fill the annular space between the drilled formations and the well casing.

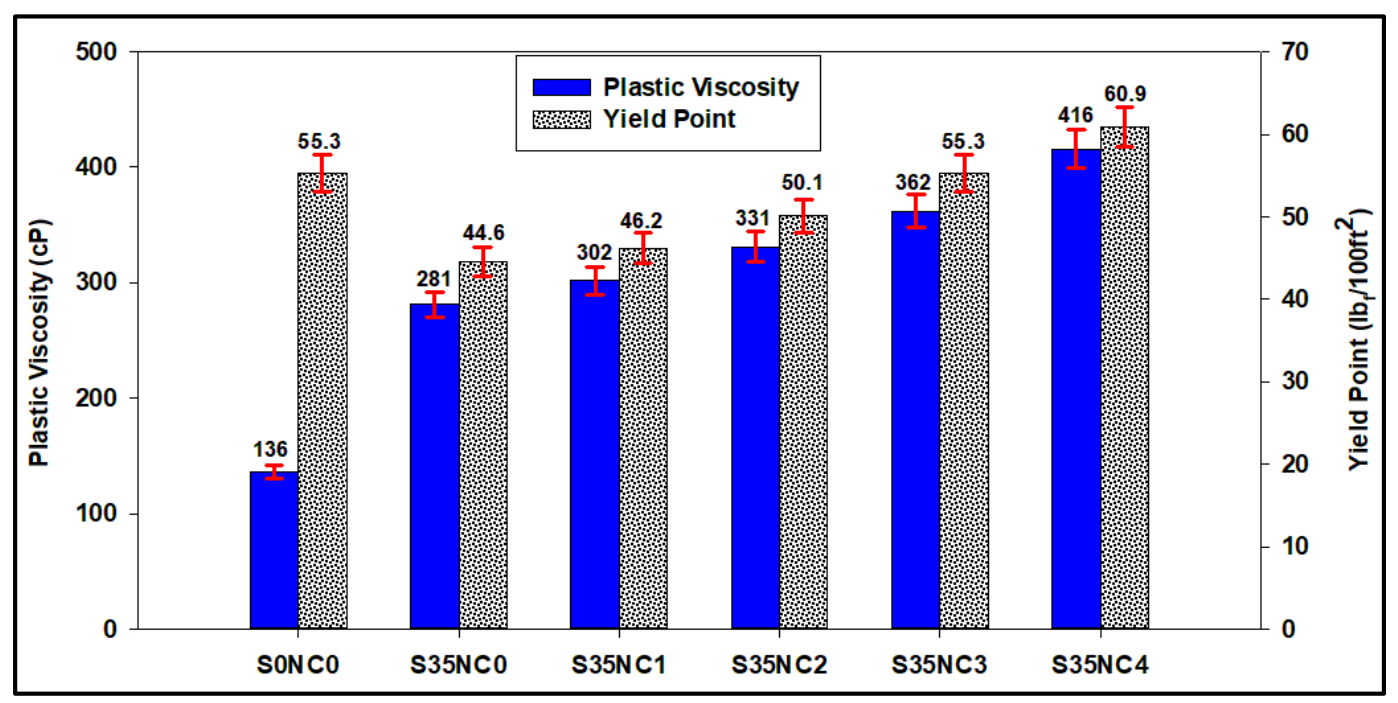

Figure 8. Comparison of the plastic viscosity and yield point for the different cement slurries.

Figure 9 compares the 10-s and 10-min GS of the different cement slurries considered in this study. The 10-s and 10-min GS of the slurry S35NC0 with no NC particles are 9.6 and $27.1 \mathrm{lb}_{\mathrm{f}} / 100 \mathrm{ft}^{2}$, respectively. Sample S35NC1 with 1\% BWOC of NC particles has 10-s and 10-min GS of 9.7 and $32.7 \mathrm{lb}_{\mathrm{f}} / 100 \mathrm{ft}^{2}$, respectively. It is clear from Figure 9 that the 10 -s and 10-min GS increased as a function of the NC concentration in the cement slurry to reach 16.0 and $43.2 \mathrm{lb}_{\mathrm{f}} / 100 \mathrm{ft}^{2}$, respectively. The GS is an important parameter needed while designing the cement slurry since it indicates the ability of the cement to keep the solids particles suspended in the solution when pumping is stopped for any reason, as well as it indicates the energy needed to resume slurry pumping again. Including NC particles into the cement slurry increased its GS, which means prevention of solids segregation and settlement of fine particles when cement circulation is stopped for any reasons, but on the other hand, this may affect the pumpability of the cement especially if the cement circulation is stopped for long time.

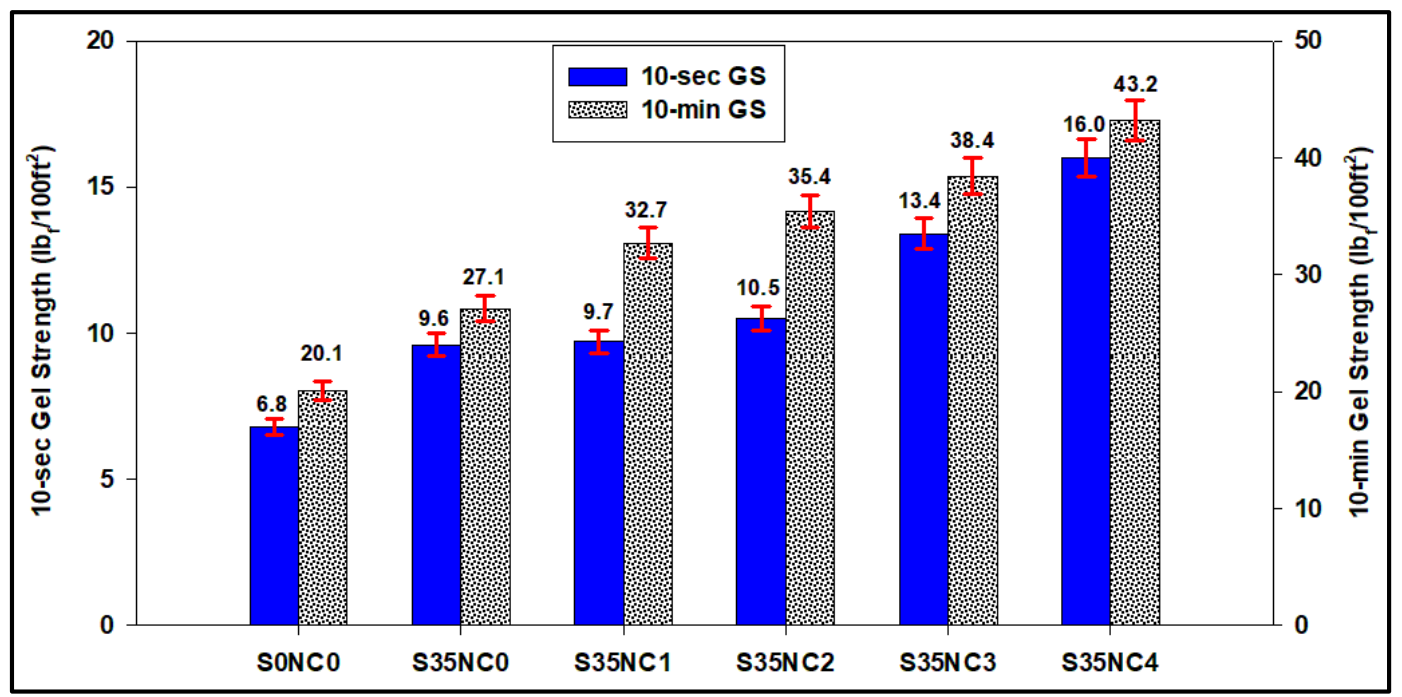

Figure 9. Comparison of the 10-s and 10-min gel strengths for all cement slurries. 


\section{Conclusions}

In this study, the effect of incorporating nanoclay particles into the cement matrix compressive and tensile strengths, permeability, and non-evaporable water content at low $\left(38^{\circ} \mathrm{C}\right)$ and high $\left(300^{\circ} \mathrm{C}\right)$ temperature conditions was evaluated. Adding nanoclay particles with concentrations not more than $3 \%$ BWOC improved the cement resistance to failure under compression and tension at low and high-temperature conditions as a result of accelerating the cement hydration reaction. It also showed a decrease in the permeability at both low and high temperatures compared to the base cement samples with and without silica flour. When the nanoclays are added with concentrations greater than $3 \%$ BWOC, agglomeration of the nanoparticles adversely affected the compressive and tensile strengths at $38^{\circ} \mathrm{C}$ and $300^{\circ} \mathrm{C}$; the permeability of the samples was also increased considerably at low temperature due to the microstructure irregularity caused by nanoparticles agglomeration and at high temperature due to samples damage and loss of non-evaporable water. The microscope images confirmed that including NC particles $(<3 \%)$ improved the pores filling of the cement matrix, while adding more $\mathrm{NC}(>3 \%)$ affected the pore structure of the cement matrix negatively by increasing concentration of the pore space of the cement. Incorporation of NC particles increased all of the cement slurry rheological properties.

Author Contributions: Conceptualization, S.E. and A.A.M.; methodology, A.A.M.; experimental, A.A.M. and A.A.; validation, S.E. and R.G.; formal analysis, A.A.M. and S.E.; investigation, R.G. and A.A.; resources, A.A.M.; writing—original draft preparation, A.A.M.; writing—review and editing, S.E. and R.G.; visualization, A.A.; supervision, S.E.

Funding: This research received no external funding.

Conflicts of Interest: The author declares no conflict of interest.

\section{Nomenclature}

$\begin{array}{ll}\text { API } & \text { American Petroleum Institute } \\ \text { BWOC } & \text { By Weight of Cement } \\ \text { CH } & \text { Calcium Hydroxide (Portlandite) } \\ \text { C-S-H } & \text { Calcium Silicate Hydrates } \\ \text { OPC } & \text { Ordinary Portland Cement } \\ \text { OWC } & \text { Oil Well Cement } \\ \text { SF } & \text { Silica Flour } \\ \text { SG } & \text { Specific Gravity } \\ \text { mD } & \text { Millidarcy } \\ \text { NC } & \text { Nanoclay }\end{array}$

\section{References}

1. Rabia, H. Well Engineering and Construction. Entrac Consulting; Entrac Petroleum: London, UK, 2001; Chapter 6; p. 203.

2. Mitchell, R.F.; Miska, S.Z. Fundamentals of Drilling Engineering; Society of Petroleum Engineers, Inc.: Richardson, TX, USA, 2011; Chapter 4; p. 139, ISBN 978-1-55563-207-6.

3. Luke, K. Phase studies of pozzolanic stabilized calcium silicate hydrates at $180^{\circ} \mathrm{C}$. Cem. Concr. Res. 2004, 34, 1725-1732. [CrossRef]

4. Vu, M.; Sulem, J.; Laudet, J.B. Effect of the curing temperature on the creep of a hardened cement paste. Cem. Concr. Res. 2012, 42, 1233-1241. [CrossRef]

5. Shahab, S.; Moradi, T.; Nikolaev, N.I.; Naseri, Y. Developing high resistant cement systems for high-pressure, high temperature applications. In Proceedings of the SPE Russian Petroleum Technology Conference, Moscow, Russia, 26-28 October 2015. [CrossRef]

6. Costa, B.L.S.; Souza, G.G.; Freitas, J.C.O.; Araujo, R.G.S.; Santos, P.H.S. Silica content influence on cement compressive strength in wells subjected to steam injection. J. Pet. Sci. Eng. 2017, 158, 626-633. [CrossRef] 
7. Wang, W.C. Compressive strength and thermal conductivity of concrete with nanoclay under Various High Temperatures. Constr. Build. Mater. 2017, 147, 305-311. [CrossRef]

8. Silva, I.B.; Martinelli, A.E.; Souza, W.R.M.; Freitas, J.C.O.; Rodrigues, M.A.F. Dilatometric behavior and crystallographic characterization of Portland-polyurethane composites for oilwell high-temperature cementing applications. J. Pet. Sci. Eng. 2018, 169, 553-559. [CrossRef]

9. Bahafid, S.; Ghabezloo, S.; Faure, P.; Duc, M.; Sulem, J. Effect of the hydration temperature on the pore structure of cement paste: Experimental investigation and micromechanical modelling. Cem. Concr. Res. 2018, 111, 1-14. [CrossRef]

10. Karim, M.R.; Chowdhury, F.I.; Zabed, H.; Saidurd, M.R. Effect of elevated temperatures on compressive strength and microstructure of cement paste containing palm oil clinker powder. Constr. Build. Mater. 2018, 183, 376-383. [CrossRef]

11. Wang, W.; Liu, X.; Guo, L.; Duan, P. Evaluation of Properties and Microstructure of Cement Paste Blended with Metakaolin Subjected to High Temperatures. Materials 2019, 12, 941. [CrossRef] [PubMed]

12. Ranachowski, Z.; Ranachowski, P.; Dębowski, T.; Gorzelańczyk, T.; Schabowicz, K. Investigation of Structural Degradation of Fiber Cement Boards Due to Thermal Impact. Materials 2019, 12, 944. [CrossRef]

13. Huang, S.; Hu, M.; Huang, Y.; Cui, N.; Wang, W. A New Model for Optimal Mechanical and Thermal Performance of Cement-Based Partition Wall. Materials 2018, 11, 615. [CrossRef] [PubMed]

14. Szelag, M. The Influence of Metakaolinite on the Development of Thermal Cracks in a Cement Matrix. Materials 2018, 11, 520. [CrossRef] [PubMed]

15. Kang, S.H.; Lee, J.H.; Hong, S.G.; Moon, J. Microstructural Investigation of Heat-Treated Ultra-High Performance Concrete for Optimum Production. Materials 2017, 10, 1106. [CrossRef]

16. Alvarez, J.; Han, S. Current overview of cyclic steam injection process. J. Petr. Sci. Res. 2013, 2, $116-127$.

17. Curtis, C.; Kopper, R.; Decoster, E.; Guzman-Garcia, A.; Huggins, C.; Knauer, L.; Minner, M.; Kupsch, N.; Linares, L.; Rough, H.; et al. Heavy-oil reservoirs; Schlumberger: Houston, TX, USA, 2002.

18. Panait-Patica, A.; Serban, D.; Ilie, N.; Pavel, L.; Barsan, N. Suplacu de Barcau Field-A Case History of a Successful In-Situ Combustion Exploitation (January 1). In Proceedings of the SPE Europec/EAGE Annual Conference and Exhibition, Vienna, Austria, 12-15 June 2006. [CrossRef]

19. Ichim, A.; Teodoriu, H.C. Investigations on the surface well cement integrity induced by thermal cycles considering an improved overall transfer coefficient. J. Pet. Sci. Eng. 2017, 154, 479-487. [CrossRef]

20. Taylor, H.F.W. Cement Chemistry, 2nd ed.; Thomas Telford: London, UK, 2004.

21. Nelson, E.B.; Guillot, D. Well Cementing, 2nd ed.; Schlumberger: Sugar Land, TX, USA, 2006.

22. Eilers, L.H.; Root, R.L. Long-term Effects of High Temperature on Strength Retrogression of Cements. In Proceedings of the Annual California Regional Meeting of the Society of Petroleum Engineers of AIME, Long Beach, CA, USA, 7-9 April 1976. [CrossRef]

23. Richardson, I.G. The calcium silicate hydrates. Cem. Concr. Res. 2008, 38, 137-158. [CrossRef]

24. Iverson, B.; Maxson, J.; Bour, D. Strength retrogression in cements under high temperature conditions. In Proceedings of the Thirty-fifth Workshop on Geothermal Reservoir Engineering, Stanford, CA, USA, 1-3 February 2010.

25. Bezerra, U.T.; Martinelli, A.E.; Melo, D.M.A.; Melo, M.A.F.; Oliveira, V.G.; Pessoa, J.; Nova, C.L. The strength retrogression of special class Portland oilwell cement. Cerâmica 2011, 57, 150-154. [CrossRef]

26. Sanjuán, M.A.; Argiz, C.; Gálvez, J.C.; Moragues, A. Effect of silica fume fineness on the improvement of Portland cement strength performance. Constr. Build. Mater. 2015, 96, 55-64. [CrossRef]

27. Stefanidou, M.; Papayianni, I. Influence of nano- $\mathrm{SiO}_{2}$ on the Portland cement pastes. Compos. Part B 2012, 43, 2706-2710. [CrossRef]

28. Hakamy, A.; Shaikh, F.U.A.; Low, I.M. Characteristics of hemp fabric reinforced nanoclay-cement nanocomposites. Cem. Concr. Compos. 2014, 50, 27-35. [CrossRef]

29. Hakamy, A.; Shaikh, F.U.A.; Low, I.M. Characteristics of nanoclay and calcined nanoclay-cement nanocomposites. Compos. Part B 2015, 78, 174-184. [CrossRef]

30. Li, Z.; Venkata, H.K.; Rangaraju, P.R. Influence of silica flour-silica fume combination on the properties of high performance cementitious mixtures at ambient temperature curing. Constr. Build. Mater. 2015, 100, 225-233. [CrossRef]

31. Rahman, M.K.; Murtaza, M.; Al-Majed, A.A.; Al-Zahrani, M.M. Nanoclay-Enhanced Cement Composition for Deep Well Treatment. US Patent US20170240469A1, 4 Sptember 2018. 
32. API Recommended Practice 10B-2-Recommended Practice for Testing Well Cements, 2nd ed.; API RP 10B-2; American Petroleum Institute: Washington, DC, USA, 2013.

33. Sanjuán, M.A.; Muñoz-Martialay, R. Influence of the age on the air permeability of concrete. J. Mater. Sci. 1995, 30, 5657-5662. [CrossRef]

34. Murtaza, M.; Rahman, M.K.; Al-Majed, A.A. Effect of Nanoclay on Mechanical and Rheological Properties of Oil Well Cement Slurry Under HPHT Environment. In Proceedings of the International Petroleum Technology Conference, Bangkok, Thailand, 14-16 November 2016.

35. Murtaza, M.; Rahman, M.K.; Al-Majed, A.A.; Samad, A. Mechanical, Rheological and Microstructural Properties of Saudi Type G Cement Slurry with Silica Flour Used in Saudi Oil Field under HTHP Conditions. In Proceedings of the SPE Annual Technical Symposium \& Exhibition, Al-Khobar, Saudi Arabia, 19-22 May 2013.

36. Mehta, P.K.; Monteiro, P.J.M. Concrete: Microstructure, Properties and Materials, 4th ed.; McGraw-Hill Professional: Berkeley, CA, USA, 2013.

37. Sanjuán, M.A.; Muñoz-Martialay, R. Oven-drying as preconditioning method for air permeability test on concrete. Mater. Lett. 1996, 27, 263-268. [CrossRef]

38. Shebl, S.S.; Allie, L.; Morsy, M.S.; Aglan, H.A. Mechanical behavior of activated nano silicate filled cement binders. J. Mater. Sci. 2009, 44, 1600-1606. [CrossRef]

39. Hakamy, A.; Shaikh, F.U.A.; Low, I.M. Thermal and mechanical properties of hemp fabric-reinforced nanoclay-cement nanocomposites. J. Mater. Sci. 2014, 49, 1684-1694. [CrossRef]

40. Farzadnia, N.; Ali, A.A.A.; Demirboga, R.; Anwar, M.P. Effect of halloysite nanoclay on mechanical properties, thermal behavior and microstructure of cement mortars. Cem. Concr. Res. 2013, 48, 97-104. [CrossRef]

41. Heikal, M.; El-Didamony, H.; Sokkary, T.M.; Ahmed, I.A. Behavior of composite cement pastes containing microsilica and fly ash at elevated temperature. Constr. Build. Mater. 2013, 38, 1180-1190. [CrossRef]

42. Heikal, M. Characteristics, textural properties and fire resistance of cement pastes containing $\mathrm{Fe}_{2} \mathrm{O}_{3}$ nano-particles. J. Therm. Anal. Calorim. 2016, 126, 1077-1087. [CrossRef]

(C) 2019 by the authors. Licensee MDPI, Basel, Switzerland. This article is an open access article distributed under the terms and conditions of the Creative Commons Attribution (CC BY) license (http://creativecommons.org/licenses/by/4.0/). 